\title{
Phosphorus recovery from waste - methods review
}

\author{
${ }^{1}$ Zbigniew Wzorek, Katarzyna Gorazda \\ Cracow University of Technology, Institute of Inorganic Chemistry and Technology, ul. Warszawska 24, 31-155 Kraków, \\ Poland, ${ }^{1}$ e-mail: wzor@chemia.pk.edu.pl,phone: +48 12 6282716, fax. +48 126282036
}

According to sustainable development principles, searching for alternative phosphorus sources, especially possible ways of its recycling from waste, should be treated as a preferential problem of the phosphorus industry. The ways admitted as most important are:

- phosphorus recovery from municipal and industrial sewage and from sewage sludge,

- utilization of phosphorus from manure

- management of waste from meat industry

The forecasts elaborated at the end of the last century, indicate that over $50 \%$ of the world phosphorus resources in use today will be depleted during the next $60-70$ years. That fact contributes to increase of market prices of phosphorus products.

This work presents possible directions for the recovery and management of sewage sludge, meat meal and manure as a phosphorus source for chemical industry.

Keywords: phosphorus recovery, waste, manure, sewage sludge, meat-bone meal.

Presented at VII Conference Wasteless Technologies and Waste Management in Chemical Industry and Agriculture, Międzyzdroje, 12 - 15 June, 2007.

\section{INTRODUCTION}

In compliance with cleaner production rules, waste should be treated as the potential source for the manufacture of new and valuable products. Sewage sludge from municipal sewage treatment as well as waste from animal production and meat industry are potential sources of phosphorus compounds and should be given as an example $^{1}$.

According to sustainable development principles, searching for alternative phosphorus sources, especially possible ways of its recycling from waste, should be treated as a preferential problem of phosphorus industry.

\section{SEWAGE AND SEWAGE SLUDGE}

Progressive urbanization accelerate the sewage prob$\mathrm{lem}^{2}$. It can be assumed that the world's annual stream of domestic sewage amounts to over $250 \mathrm{~km}^{3}$.

Modern sewage treatment methods use physical, biological and chemical processes in different sequences. Integrated method of nitrogen and phosphorus removal take advantage of extraordinary abilities of some bacteria for phosphorus compounds accumulation (eg. Acinetobacter-Moraxella-Mima lub Aeromonas i Pseudomonas Spp. $)^{\mathbf{3}, 4}$. That features are used in such processes as: Biological Phosphorus Removal (BPRPHOSTRIP), BARDENPHO Or JOHANNESBURG PROCESS 5,6 .

The mechanism of sewage stream enrichment during the anaerobic process became the basis of series of methods, for phosphorus recovery from sewage in the form of useful products: calcium phosphates or struvite.

Calcium phosphate precipitation is carried out with $\mathrm{CaO}$, by it's addition in the form of lime milk. As $\mathrm{pH}$, molar ratio and the concentration achieve the required level, the amorphous precipitates are received, which then crystallises to phosphates: $\mathrm{CaHPO}_{4} \cdot 2 \mathrm{H}_{2} \mathrm{O}$ (DCPD), $\mathrm{Ca}_{8} \mathrm{H}_{2}\left(\mathrm{PO}_{4}\right)_{6} \cdot 5 \mathrm{H}_{2} \mathrm{O}(O C P)$ i $\mathrm{Ca}_{10}\left(\mathrm{PO}_{4}\right)_{6} \cdot(\mathrm{OH})_{2}(H A)^{5,6,7}$.
The best known method of calcium phosphate crystallization is DHV Crystalactor in the fluidised-bed crystallizer ${ }^{6}$. The sands grains $(0,1-0,6 \mathrm{~mm})$ are used for crystallization seeding and the process is carried out at the $\mathrm{pH}$ range between $10-10.5$.

Many papers and research have given attention to crystallization of struvite - magnesium-ammonium phosphate - $\mathrm{MgNH}_{4} \mathrm{PO}_{4} \cdot 6 \mathrm{H}_{2} \mathrm{O}$ containing $9.9 \% \mathrm{Mg}, 12.62 \% \mathrm{P}$, $5.71 \% \mathrm{~N}$, which can be successfully used for fertilizing purposes ${ }^{7}$.

Initially phosphorus recovery was not the reason of interest of potential struvite precipitation, but the necessity of its removal from the sewage streams. The magnesium-ammonium phosphate with molar ratio $\mathrm{Mg}: \mathrm{NH}_{4}: \mathrm{PO}_{4}$ as 1:1:1 precipitates spontaneously causing the installations overgrowing ${ }^{\mathbf{5}, \mathbf{8}, \mathbf{9}}$.

In the Republic of South Africa the crystallization method CSIR with fluid-bed was developed ${ }^{6}$. The method consist in phosphorus removal in the form of granulated struvite. Struvite is recovered in the reactor under favourable conditions for crystallization: supersaturated solution, $\mathrm{pH}>8$, in the presence of fly-ash and schist as crystallization seeds.

Three-stage process of struvite precipitation, Phosnix Unitika, use the biologically enriched with phosphorus sewage stream ${ }^{6,10}$.

\section{METHODS OF SEWAGE SLUDGE NEUTRALIZATION AND MANAGEMENT}

The sewage treatment methods generate significant quantities of waste. In Poland at the end of the XX century, nearly 360000 tons of sewage sludge, as dry matter were produced, which consisted of 13500 tons of $\mathrm{P}_{2} \mathrm{O}_{5}$. In accordance with forecasts till the end of the year 2015 that amounts will be doubled ${ }^{2}$.

The agricultural use of sewage sludge create a serious menace connected with introducing into the ground sig- 
nificant quantities of heavy metals and pathogenic organisms.

Sewage sludge are also applied for compost production $^{11}$. That process can be managed with direct sewage sludge composting or together with segregated municipal waste, plant biomass and waste from food industry. Compost usability will be determined by heavy metals content as well as in the case of direct use of sewage sludge.

The most known technology of phosphorus compounds recovery from sewage sludge was elaborated by Kemira ${ }^{\mathbf{1 2}}$, 13, 14, 15. The KREPRO process (Kemwater REcycling PROcess) depends on thermal hydrolysis of sewage sludge in the sulphuric acid environment. Sewage sludge thickened to $5-7 \%$ of dry mass are mixed with sulphuric acid to $\mathrm{pH}$ between 1 to 3 . Acidified suspension is heated in the autoclave to the temperature of $140^{\circ} \mathrm{C}$. As a result of the process nearly $40 \%$ of organic matter are hydrolyzed into liquid form, easily biodegradable, which can be used as a carbon source in the denitrification processes. Most of the inorganic compounds from sewage sludge are also dissolved. The solution after centrifugation is directed into the reactor, where the $\mathrm{pH}$ is raised to the range needed for orthophosphate precipitation in the form of $\mathrm{FePO}_{4}$. The scheme of the process is shown in figure 1.

The Cambi/KREPRO process, which is the combination of solutions known before, became the development of the above technology ${ }^{\mathbf{1 2}}$. According to modified technology the hydrolysis of sewage sludge with $20 \%$ of dry matter content is possible. The excess of $\mathrm{Fe}^{3+}$ ions necessary for $\mathrm{FePO}_{4}$ precipitation can be turned back into the neutralizer or used as a coagulant in sewage treatment plant.

German Seaborne Environmental Research Laboratory Gmbh elaborate the method of complex sewage sludge treatment in connection with biogas purifying and phosphorus and nitrogen recycling ${ }^{\mathbf{1 6}, 17}$. In this process, the mixture of sewage sludge after the fermentation process with ash after its combustion, are acidolised. In the reactor the hydrolysis of the sewage sludge and simultaneous solution of mineral components, also phosphorus compounds, are proceeded. The organic fraction after centrifugation is incinerated and struvite is produced from the solution. The scheme of the Seaborne process is show in figure 2.

In the BioCon process, the ash after sewage sludge combustion in the grid furnace in the temperature of $1123 \mathrm{~K}$ $\left(850^{\circ} \mathrm{C}\right)$ is used. The ash after milling is treated with sulphuric acid $(\mathrm{pH} \sim 1)$. Appling the ion exchange method, allows for the removal of components on separate stages and phosphorus recovery in the form of phosphoric acid and iron in the form of $\mathrm{FeCl}_{3}{ }^{12}, 16$

Phosphorus recovery from ashes is also realized in the SEPHOS method (SEquential precipitation PHOSphorus). The ash from sewage sludge after simultaneous sewage treatment with $\mathrm{Al}^{3+}$ ions, is leached with sulphuric acid $(\mathrm{pH}<1,5)$. After the suspension is being separated the $\mathrm{pH}$ of the solution is raised to 3.5 by the addition of the soda lye, $\mathrm{AlPO}_{4}$ and most of the heavy metals precipitates in consequence. The residue can be used for phosphorus production by the electrochemical method ${ }^{\mathbf{1 6}}$.

The ashes after sewage sludge combustion as well as after pyrolysies in the temperature $400-700^{\circ} \mathrm{C}$ can be use for phosphorus production ${ }^{18}$. The required condition is low content of iron, zinc and cooper.

\section{WASTE FROM MEAT INDUSTRY}

Till the end of the 90's, waste from the meat industry was mainly used for production of meat meals and meatand-bone meals ${ }^{19}$. In connection with Creutzfeldt-Jakob (CDJ) disease the European Union systematically introduced regulations liming use of meals for feed purposes ${ }^{\mathbf{2 0}}$.

The main direction for utilization of meat industry waste is thermal neutralization and also combustion and cocombustion for energetic purposes. The heat of combustion for meat-and-bone meal is near $18500 \mathrm{~kJ} / \mathrm{kg}$. Such a igh value of combustion heat allowes for using meat-andbone meal in the cement industry. The waste is mixed with raw materials and burned in the temperature of $1500^{\circ} \mathrm{C}$. In France nearly $45 \%$ from $850000 \mathrm{t}$ of bone meal is combusted at the cement plant. In the United States approximately 30 plants work, which use meat-andbone meal for cement production ${ }^{21,22,23}$. Waste are also combusted in cement furnace in Poland.

Relatively small groups of papers give attention to recycling possibilities of crude side-products from the meat industry. One of the possible directions for use of sideproducts after slaughter (also meat-and-bone-meal) is pyrolysis.

Phosphorus content in meat-and-bone meal amounts to $3-6 \%$, calcium to $8-10 \%$. Ashes after meals combus-

\section{Sulfuric acid}
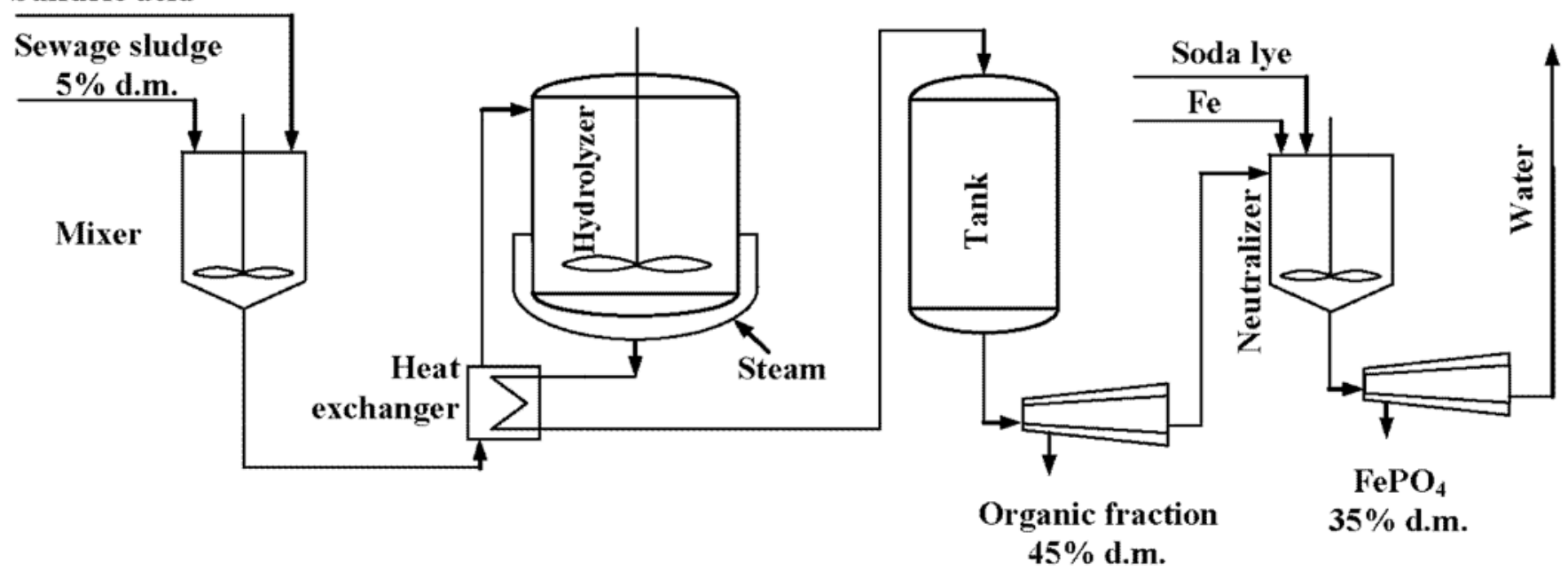

Figure 1. The scheme of KREPRO process 


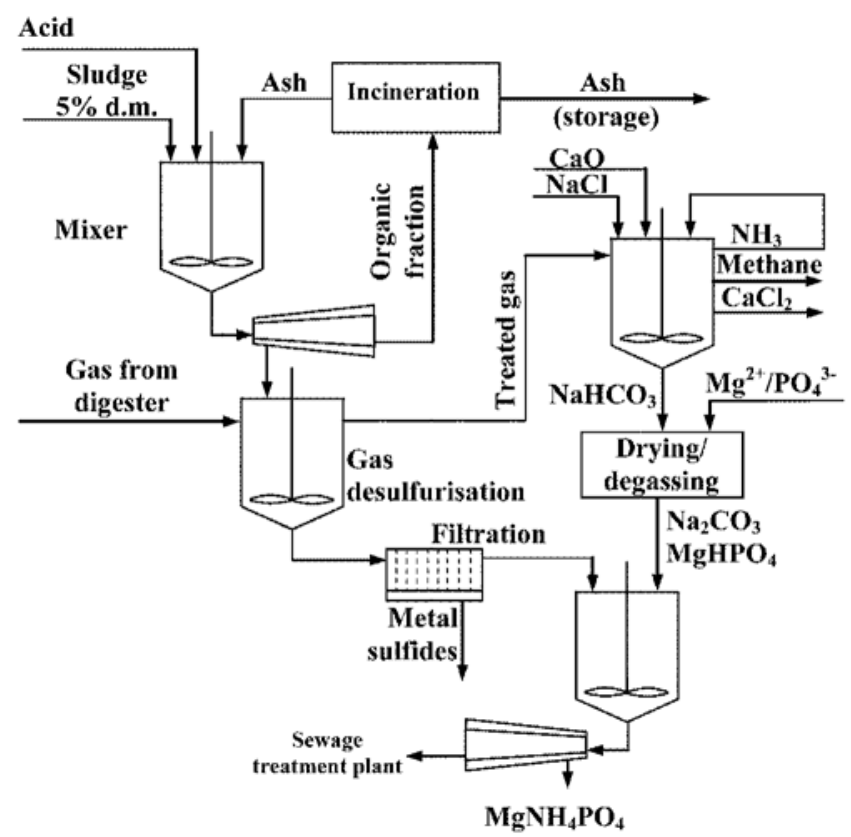

Figure 2. The scheme of the Seaborne process

tion contain adequately $15-16.5 \% \mathrm{P}$ and $29.5-33 \% \mathrm{Ca}$ in dependence of combustion conditions ${ }^{21}$. The main components of ash after meat-and-bone meal combustion are: hydroxylapatite, $\beta-\mathrm{Ca}_{3}\left(\mathrm{PO}_{4}\right)_{2}$, also small quantities of sodium, potassium and magnesium. That product is practically devoid of heavy metals in contrast with natural apatite and phosphorite. Chemical properties of ashes indicate that they can be successfully used in the chemical industry for phosphoric acid and its derivatives production.

Ashes after bone waste combustion are used for porcelain production, so-called Bone China. The production technology of bone china was developed in XVII century in Great Britain as a supplement of china porcelain. It is manufactured from bone ash $(30-50 \%$ of mixture $)$, clay, kaolin and feldspar ${ }^{24}$.

Hydroxylapatite received from meat waste can find application in implantology. The basis of that theory is biocompatibility and structural similarity of hydroxylapatite from animal origin to mineral elements of human bones. These properties cause that hydroxylapatite obtained from animal bones is osteoinductive, that means that after its implantation, natural bone substitutes the implant ${ }^{24}$.

\section{Waste from animal production}

It is generally considered that manures are ,natural” side-products, which can be used for fertilizer purposes, and its negative influence on natural environment is lower than in the case of using commercial mineral fertilizers. Meanwhile the nitrogen losses as a result of washing out into underground water are in both cases comparable. Moreover manure consists of relatively high phosphorus content, which can be washed out into subcutaneous water as a consequence of erosion, creating a negative environmental effect ${ }^{26}$.

Manuring that takes into account crop demand for nitrogen, takes effect mostly with excessive phosphorus load introduced into the soil ${ }^{27}$. The N:P ratio recommended for cultivation is on the level close to 4.5-6.0: 1 depend- ing on cultivation, while the $\mathrm{N}: \mathrm{P}$ ratio in manure is close to $1,5-5,0: 1$.

Agriculture in collaboration with industry is forced to elaborate rational management systems, for waste from animal production. Manure can become a valuable raw material for chemical industry, especially phosphoric acid. In manure generated yearly in Great Britain phosphorus content attain 120000 tones. It is approximately twice the time higher value than annual demand of that country for phosphorus products used for non-agricultural purposes 28 . Similar phosphorus load is accumulated in manure generated in Holland. In the United States these quantities are estimated to 600000 tones. Manures have deferent properties dependent on spices, age and the way of animals feeding. Therefore the way of different manure utilization should be adapted to the kind of waste.

In Poland most phosphorus is concentrated in poultry manure. Annual load can be estimated near 80000 tons of phosphorus. With the manure from cattle production nearly 34000 tons of pure element is dropped, while from swine production next 40000 tons. Presently a large majority of manure from poultry farms is used directly for fertilising purpose. Part of the manure is dried and obtained granulate is merchandise as a horticultural fertilizer.

Cattle manure characterises high fertilizing value. $90 \%$ of phosphorus is bounded in the water insoluble form, its separation from manure is very difficult. The research are concentrated on struvite precipitation from eluates obtained from solid parts processing, eg. Fermentation in anaerobic condition or oxidation (AOP - advanced oxidation process $)^{\mathbf{2 9}, \mathbf{3 0}}$.

Similar to cattle production, $90 \%$ of phosphorus in the manure from swine production is insoluble in water. Therefore water separation allows for obtaining a solid fraction with high phosphate content. From that fraction via biochemical processes it is possible to obtain a solution with high phosphate and ammonium ions concentration, allowing for struvite or calcium phosphate precipitation $^{31,32}$.

The SELCO process introduced in Italy, Spain and United States allows for complex processing of manure from swine production. In that process at the first stage solid from liquid fraction is separated with the use of coagulant - polyacryloamide ${ }^{33}$. The mineral components from liquid fraction can be released and used for fertilizer purposes. The solid phase is directed for biogas production.

\section{SUMMARY}

Civilization development is connected with generation of continuously growing quantities of waste. It can be considered that especially strenuous for environment are: sewage sludge from sewage treatment, waste from the meat industry and animal production. According to European Union priorities in the field of waste management it is advisable to undertake the studies aimed at reducing the quantities of stored waste and utilization of its component ${ }^{11}$.

From among the discussed waste, manure from animal production has the highest level of use. Its nitrogen and phosphorus content makes it a valuable fertilizer. How- 
ever in the consequence of strong concentration of the stock farms using manure in the place of its forming, it becomes frequently impossible. Introduction of excessive biogenic components into soil produce increasing menace of eutropication in water reservoirs.

Until recently waste from the meat industry were used for feeding purpose. The menace of the Creutzfeldt-Jakob disease caused serious industrial problems with its neutralization and management of immense quantities of sideproducts. While all that waste can be valuable raw material for the chemical industry, for phosphoric acid and its salts production.

Undoubtedly sewage sludge causes the greatest problems with its management. That hazardous waste carry significant amounts of elements and compounds harmful for the environment. Therefore utilization of that type of waste connected with simultaneous recovery of valuable mineral components should be considered as an especially important for the environment.

\section{LITERATURE CITED}

(1) Richards I. R., Johnston A. E.: The effectiveness of different precipitated phosphates as sources of phosphorus for plants, Report on work undertaken for CEEP, EFMA (European Fertiliser Manufacturers Association), Anglian Water UK, Thames Water UK and Berlin Wasser Betriebe, December 2001.

(2) Rzepecki T.: Badania nad utylizacją odpadów $\mathrm{Z}$ procesów z oczyszczania ścieków komunalnych i odzyskiem z nich związków fosforu, Praca Doktorska, Politechnika Krakowska, 2003.

(3) Kuroda A., Takiguchi N., Gotanda T., Nomura K., Kato J., Ikeda T., Ohtake H.: A simple method to release polyphosphate from activated sludge for phosphorus reuse and recycling. Biotech. Bioeng., 2002, 78, 3, 333 - 338.

(4) Morohoshi T., Maruo T., Shirai Y., Kato J., Ikeda T., Takiguchi N., Ohtake H., Kuroda A.: Accumulation of inorganic polyphosphate in phoU mutants of Escherichia coli and Synechocystis sp. Strain PCC6803. Appl. Environ. Microbiol., 2002, 68, 8, 4107 - 4110.

(5) Phosphate recovery and removal from wastewaters, Phosphorus \& Potassium, 1998, 213, $30-39$.

(6) Brett S., Guy J., Morse G. K., Lester J. N.: Phosphorus removal and recovery technologies, Selper Publications, London, 1997.

(7) Strickland J.: Perspectives for phosphorus recovery offered by enhanced biological removal, Env. Tech., 1999, 20, $721-725$.

(8) Gorazda K., Wzorek Z., Jodko M., Nowak A. K.: Struwit własności fizykochemiczne i zastosowanie. Część I, Chemik, 2004, 57, 1, 8 - 13.

(9) Gorazda K., Wzorek Z., Jodko M., Nowak A. K.: Struwit - metody wytwarzania. Część II, Chemik, 2004, 57, 9, $317-320$.

(10) Pilot-scale struvite recovery reactor, CEEP Scope Newsletter, 2001, 41, 23 - 24.

(11) Rosik-Dulewska Cz.: Podstawy gospodarki odpadami, Wydawnictwo Naukowe PWN, Warszawa, 2005.

(12) Dulley B.: Recycling phosphorus by recovery from sewage, Second International Conference on recovery of phosphorus from sewage and animal wastes, Noordwijkerhout, Netherlands, 12 - 13 march 2001.

(13) Hansen B., Karlsson I., Cassidy S., Pettersson L.: Operational experiences from a sludge recovery plant, Water Sci. Technol., 2000, 41, 8, 23 - 30.

(14) Odegaard H., Paulsrud B, Karlsson I.: Wastewater sludge as a resource: Sludge disposal strategies and corre- sponding treatment technologies aimed at sustainable handling of wastewater sludge, Water Sci. Technol., 2002, 46, 10, $295-303$.

(15) Levlin E., Löwén M., Stark K., Hultman B.: Effects of phosphorus recovery requirements on Swedish sludge management, Water Sci. Technol., 2002, 46, 4-5, 435 - 440.

(16) Berg U., Schaum C.: Recovery of phosphorus from sewage sludge and sludge ashes - applications in Germany and Northern Europe, I. Ulusal Aritma Çamurlari Sempozyumu AÇS2005, 23 - 25 Mart 2005, Izmir, 87 - 98.

(17) Stark K.: Phosphorus recovery - experiences from European countries, Integration and optimisation of urban sanitation systems., Plaza E., Levlin E., Hultman B. (Editors), Proceedings of Polish-Swedish seminars, Stockholm June 6 - 8, 2004.

(18) Schipper W. J., Klapwijk A., Potjer B., Rulkens W. H., Temmink B. G., Kiestra F. D. G., Lijmbach A. C. M.: Phosphate recycling in the phosphorus industry, Environ. Technol., 2001, 22, 11, 1337 - 1345.

(19) Jamroz D.: Witold Podkówka i Jadwiga Chachułowa (red.), Żywienie zwierząt i paszoznawstwo, PWN, Warszawa, 2001.

(20) Willesmith J. W.: Manual on bovine spongiform encephalopathy, Food and Agriculture Organization of the United Nations, Rome, 1998.

(21) Deydier E., Guilet R., Sarda S., Sharrock P.: Physical and chemical characterisation of crude meat and bone meal combustion residue: „waste or raw material?” J. Hazard. Mater., 2005, B121, 141 - 148.

(22) Price G.: Castle's alternative action, 2006, World Cement, 37, 6, $41-45$.

(23) Conesa J. A., Fullana A., Font R.: Dioxin production during the thermal treatment of meat and bone meal residues, Chemosphere, 2005, 59, 85 - 90.

(24) Bragança S. R., Bergmann C. P.: Production of bone porcelain and characterization of its technical properties, Ceramica, 2006, 52, 322, 205 - 212.

(25) Conz M. B., Granjeiro J. M., Soares G. A.: Physicochemical characterization of six commercial hydroxyapatites for medical-dental applications as bone graft, Journal of Applied Oral Science, 2005, 13, 2, 136 - 140.

(26) Adeli A., Sistani K. R., Rowe D. E., Tewolde H., Effects of broiler litter on soybean production and soil nitrogen and phosphorus concentration, Agron. J., 2005, 97, 1, $314-321$.

(27) Eghball B.: Phosphorus and nitrogen based manure and compost application, Manure Matters, 1996, 2, 9.

(28) Greaves J., Hobbs P., Chadwick D., Haygarth P.: Prospects for the recovery of phosphorus from animal manures: a review, Environ. Technol., 1999, 20, 7, 697 - 708. Czech Republic, 26 - 28.06.2003, 167 - 170.

(29) Zeng L., Li X.: Nutrient removal from anaerobically digested cattle manure by struvite precipitation, J. Environ. Eng. Sci., 2006, 5, 4, 285 - 294.

(30) Qureshi A., Lo K. V., Mavinic D. S., Liao P. H., Koch F., Kelly H.: Dairy manure treatment, digestion and nutrient recovery as a phosphate fertilizer, J. Environ. Sci. Heal. B, 2006, 41, 7, 1221 - 1235.

(31) Maekawa T., Liao C. M., Feng X. D.: Nitrogen and phosphorus removal for swine wastewater using intermittent aeration batch reactor followed by ammonium crystallization process, Wat. Res., 1995, 29, 12, 2643 - 2650.

(32) Kalyuzhnyi S., Sklyar V., Epov A., Arkhipchenko I., Barboulina I., Orlova O., Klapwijk A.: Combined biological and physico-chemical treatment of filtered pig manure wastewater: Pilot investigations, Wat. Sci. Technol., 45, 12, 79 $-87$.

(33) Martinez-Almela J., Barrera J. M.: SELCO-Ecopurin ${ }^{\circledR}$ pig slurry treatment system, Bioresource Technol., 2005, 96, $223-228$. 